\title{
Effect of Tempering Temperature on the Low Temperature Impact Toughness of 42CrMo4-V Steel
}

\author{
Chen Sun 1,2, Pai-Xian Fu 1,2,*, Hong-Wei Liu 1,2, Hang-Hang Liu ${ }^{1,2}$ and Ning-Yu Du ${ }^{1,2}$ \\ 1 Institute of Metal Research, Chinese Academy of Sciences, 72 Wenhua Road, Shenyang 110016, China; \\ csun15s@imr.ac.cn (C.S.); hwliu@imr.ac.cn (H.-W.L.); hhliu15b@imr.ac.cn (H.-H.L.); \\ nydu16s@imr.ac.cn (N.-Y.D.) \\ 2 School of Materials Science and Engineering, University of Science and Technology of China, \\ 72 Wenhua Road, Shenyang 110016, China \\ * Correspondence: pxfu@imr.ac.cn; Tel.: +86-242-397-1973
}

Received: 7 March 2018; Accepted: 29 March 2018; Published: 2 April 2018

\begin{abstract}
Effects of tempering temperature on the microstructures and low temperature impact toughness of $42 \mathrm{CrMo} 4-\mathrm{V}$ steel were investigated. Microstructures of $42 \mathrm{CrMo} 4-\mathrm{V}$ steel after tempering at $570-720^{\circ} \mathrm{C}$ for $3 \mathrm{~h}$ were experimentally investigated using scanning electron microscopy (SEM), electron back-scattered diffraction (EBSD), transmission electron microscopy (TEM) and X-ray diffraction (XRD). The results showed that the carbide precipitation sequence of $42 \mathrm{CrMo4}-\mathrm{V}$ steel is $\mathrm{M}_{8} \mathrm{C}_{7} \rightarrow \mathrm{M}_{3} \mathrm{C}$ and the absorbed energies of $42 \mathrm{CrMo} 4-\mathrm{V}$ steel increase greatly from $21.7 \mathrm{~J}$ to $132.3 \mathrm{~J}$ with increasing tempering temperature from $570{ }^{\circ} \mathrm{C}$ to $720^{\circ} \mathrm{C}$. The changes of impact toughness with increasing tempering temperature were attributed to the softening of matrix, the evolution of carbide precipitates and grain structures.
\end{abstract}

Keywords: 42CrMo4-V steel; vanadium; tempering temperature; carbide precipitates; low temperature impact toughness

\section{Introduction}

AISI 4140 or $42 \mathrm{CrMo} 4$ is a low-alloy structural steel widely used in important structural components such as generator spindle, crane weight-on-wheel, automotive crankshafts [1], oil drill pipe joints of deepwell, armour materials [2] and other applications [3,4].

$42 \mathrm{CrMo} 4$ steel has attracted great attention due to its high strength and toughness, an interesting fatigue behavior and good machinability [5-7]. Fatigue behavior was the most popular research direction. Various factors such as heat treatment [8], environmental temperature [9], residual stress [10] and chemical element [11] were taken into consideration towards improving fatigue performance of the material. Surface treatment [12] and wear resistance [13] were another two focusing issues. Surface nitriding treatment and laser surface hardening were still the main directions to improve the wear resistance of tool steel. In addition, strengthening measures, welding performances and corrosion protection treatments were also studied in published researches.

$42 \mathrm{CrMo} 4$ steels was one of the main manufacturing steel for the main shaft of wind generators. The main shaft is required to work at a low temperature in safe and reliable service conditions for more than 20 years [14]. Meanwhile, the main shaft will be experience tensile, bending and shear stresses as well as varying extreme weather conditions [15]. Therefore, a preferable low temperature impact toughness was necessary for the main shaft that worked in cold weather. For most parts of China, the coldest temperature needs to be set at $-30{ }^{\circ} \mathrm{C}$ in order to guarantee safe operation of the wind generator. However, low temperature impact toughness, especially at $-30{ }^{\circ} \mathrm{C}$ or below, was rarely reported. 
With the development of wind generator operated at low temperature and at large size, the adjustment of heat treatment alone was unsuccessful in producing $42 \mathrm{CrMo} 4$ steel that could satisfy the requirement of the main shaft, so the optimization of chemical composition was necessary. The vanadium element could refine grain size significantly, while also enabling formation of tiny $V(C, N)$ particles that prevent crack propagation [16,17]. In addition, the grain refinement effect of vanadium as well as the formation of $\mathrm{V}(\mathrm{C}, \mathrm{N})$ particles also have an important influence on the ductile-brittle transition temperature $[18,19]$. Therefore, a moderate addition of vanadium could improve both strength and toughness. Our group developed the $42 \mathrm{CrMo} 4-\mathrm{V}$ steel by adding an appropriate amount vanadium, and hoping that would obtain a favorable low temperature impact toughness to meet the challenges.

Vanadium was a strong carbide forming element, so the addition of vanadium could have an influence on the precipitation of carbides. Besides, the optimization of chemical composition always led to the adjustment of heat treatment system. In the production processes of the main shaft, tempering is the key process to improve toughness. In order to promote the industrial application of $42 \mathrm{CrMo} 4-\mathrm{V}$ steel, it is necessary to clarify the relationship between its low temperature impact toughness and tempering temperature. Thus, the present work has been aimed to evaluate the carbide precipitates and low temperature impact toughness of the $42 \mathrm{CrMo} 4-\mathrm{V}$ steel subjected to tempered at various temperature.

\section{Experimental Procedures}

The 42CrMo4-V steel used in this investigation was smelted in an electric furnace and refined through a procedure of ladle furnace (LF), vacuum degassing furnace (VD). Then the ingot was forged into a stepped shaft. Specimens with dimensions of $60 \mathrm{~mm} \times 60 \mathrm{~mm} \times 60 \mathrm{~mm}$ were taken from the shaft, and the chemical composition is given in Table 1. The heat treatment process included normalizing, quenching, and tempering. The normalizing temperature was selected to be $840{ }^{\circ} \mathrm{C}$ for $3 \mathrm{~h}$, followed by air cooling. The quenching temperature was $860^{\circ} \mathrm{C}$ for $3 \mathrm{~h}$ followed by water cooling. Then, the tempering was performed at $570,600,630,660,690$ and $720^{\circ} \mathrm{C}$ for $3 \mathrm{~h}$ followed by air cooling.

Table 1. Chemical compositions of $42 \mathrm{CrMo} 4-\mathrm{V}$ steel and traditional $42 \mathrm{CrMo} 4$ steel (wt. \%).

\begin{tabular}{cccccccccc}
\hline Alloy & $\mathbf{C}$ & $\mathbf{S i}$ & $\mathbf{M n}$ & $\mathbf{C r}$ & $\mathbf{M o}$ & $\mathbf{S}$ & $\mathbf{P}$ & $\mathbf{N i}$ & $\mathbf{V}$ \\
\hline 42CrMo4-V & 0.40 & 0.25 & 0.73 & 1.12 & 0.26 & 0.0001 & 0.010 & 0.53 & 0.19 \\
$42 \mathrm{CrMo} 4$ & $0.38-0.45$ & $0.17-0.37$ & $0.50-0.80$ & $0.90-1.20$ & $0.15-0.25$ & $\leq 0.035$ & $\leq 0.035$ & - & - \\
\hline
\end{tabular}

The microstructures of the tempered samples were observed by scanning electron microscopy (SEM, S-3400N, Hitachi Company, Tokyo, Japan) and transmission electron microscopy (TEM, Tecmai $\mathrm{G}^{2} 20$, FEI Company, Hillsboro, OR, USA). SEM specimens were polished and etched with 4 vol. \% nital solution. TEM samples were firstly made into $3 \mathrm{~mm}$ in diameter and $50 \mu \mathrm{m}$ in thickness, and then were electropolished by using a solution with $10 \mathrm{vol} . \%$ perchloric acid and $90 \mathrm{vol}$. $\%$ alcohol at a voltage of $25 \mathrm{~V}$ and a temperature ranging between $-30{ }^{\circ} \mathrm{C}$ and $-20^{\circ} \mathrm{C}$. The grain orientations were observed by Electron-backscattered diffraction (EBSD) with a step size of $0.5 \mu \mathrm{m}$. Only the results with a hit rate more than $90 \%$ were used. The surface stress of EBSD samples was removed by ion etching at a voltage of $3.5 \mathrm{kV}$, a current of $1.5 \mathrm{~mA}$ and an angle of $15^{\circ}$.

The precipitates were characterized using X-ray diffraction (XRD, D/Max-2500PC, Rigaku Company, Tokyo, Japan) with $\mathrm{Cu}-\mathrm{K} \alpha(\lambda=1.5406 \AA)$ with a scanning angle from $40^{\circ}$ to $100^{\circ}$ and a scanning speed of $2^{\circ} / \mathrm{min}$. And carbide powder for the XRD tests was extracted by using a solution with 10 vol. \% hydrochloric acid and 90 vol. \% methanol.

Charpy V-notch specimens with gauge size of $10 \mathrm{~mm} \times 10 \mathrm{~mm} \times 55 \mathrm{~mm}$ were conducted on RKP450 (Zwick-Roell Company, Ulm, Germany)impact testing machine using a $300 \mathrm{~J}$ hammer at $-30{ }^{\circ} \mathrm{C}$. Three experiments were conducted on each test condition. And then, the fracture surfaces were characterized by SEM (S-3400N). 


\section{Results and Discussion}

\subsection{Microstructures}

Figure 1 shows the SEM microstructures of 42CrMo4-V steel tempered at different temperatures, indicating that martensite laths are gradually recovered with increasing tempering temperature. TEM micrographs reflect this trend more clearly, as shown in Figure 2. The martensite lath boundaries remain intact after being tempered at $570{ }^{\circ} \mathrm{C}$ (Figure 2a). While after being tempered at $630{ }^{\circ} \mathrm{C}$ (Figure $2 b$ ), the lath boundaries still exist, but its integrity reduces. As the temperature increased further, the dislocations in $\alpha$ phase gradually merge and annihilate, then the residual dislocations are gradually polygonized in the form of subgrains, resulting in the recovery of lath boundaries (Figure 2c,d) [20-22]. Moreover, as already reported [22,23], the dislocation density decreases with increasing tempering temperature while there still contains a high density of dislocations even after $720{ }^{\circ} \mathrm{C}$ tempering (Figure $2 \mathrm{~d}$ ).
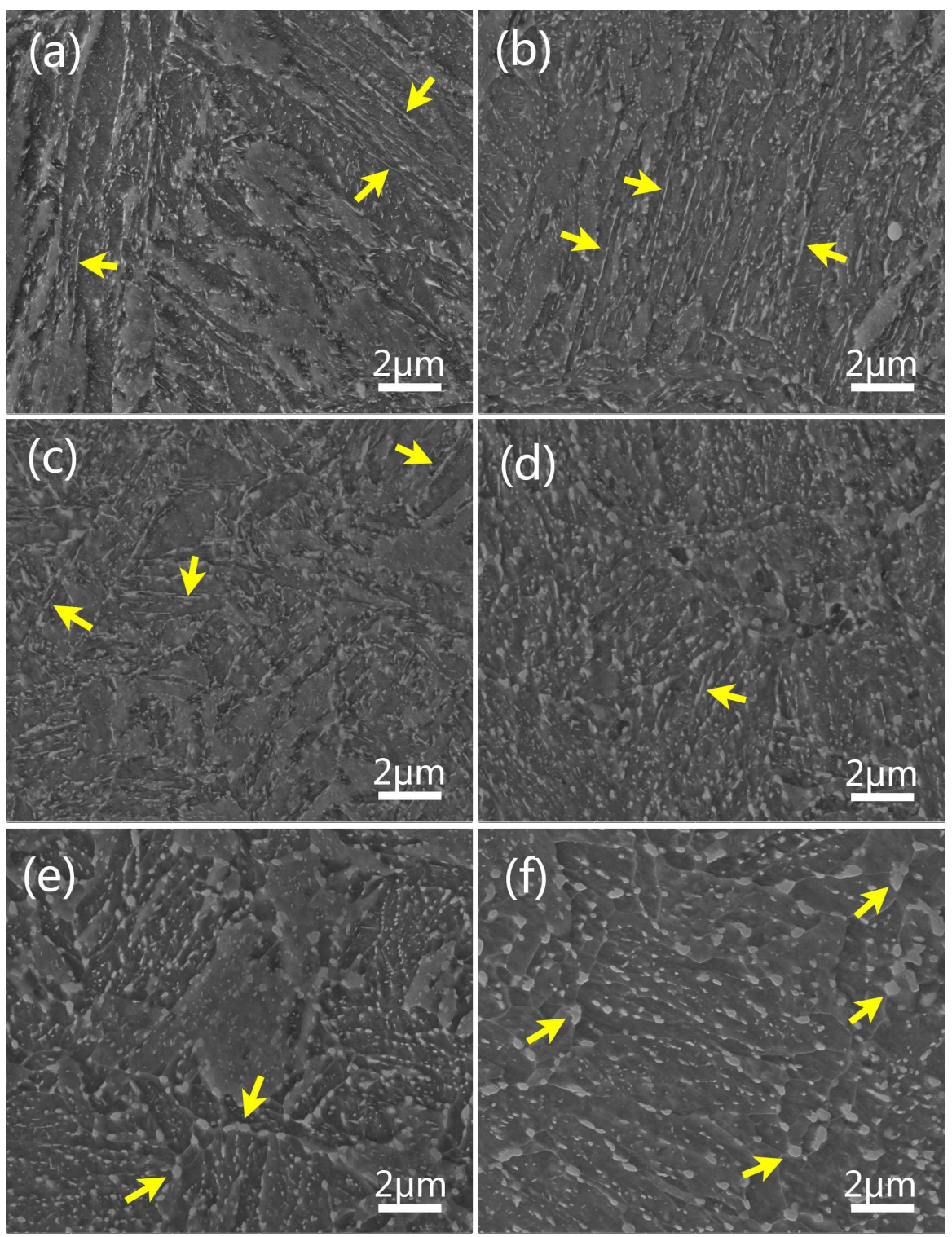

Figure 1. SEM microstructures of $42 \mathrm{CrMo} 4-\mathrm{V}$ steel tempered at: (a) $570{ }^{\circ} \mathrm{C}$; (b) $600{ }^{\circ} \mathrm{C}$; (c) $630{ }^{\circ} \mathrm{C}$; (d) $660{ }^{\circ} \mathrm{C}$; (e) $690^{\circ} \mathrm{C}$; (f) $720^{\circ} \mathrm{C}$. 

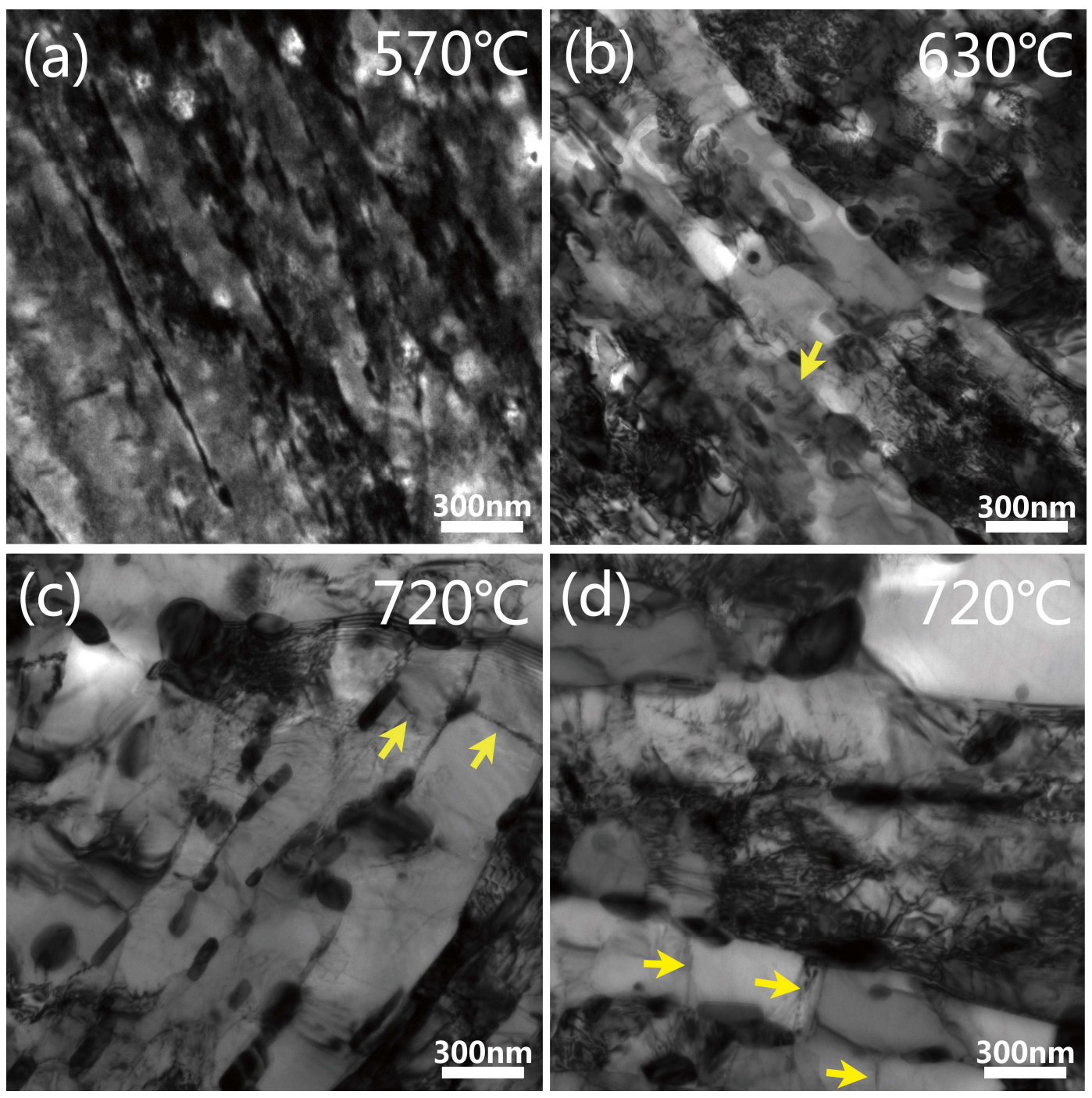

Figure 2. TEM images showing the recovery of martensite lath in $42 \mathrm{CrMo4}-\mathrm{V}$ steel tempered at: (a) $570{ }^{\circ} \mathrm{C}$; (b) $630{ }^{\circ} \mathrm{C}$; (c) $720^{\circ} \mathrm{C}$; (d) $720^{\circ} \mathrm{C}$.

Figure 1 reflects not only the recovery of martensite laths, but also the evolution of carbides with increase in tempering temperature. After being tempered at $570{ }^{\circ} \mathrm{C}$ (Figure 1a) and $600{ }^{\circ} \mathrm{C}$ (Figure 1b), carbides precipitate preferentially along the martensite lath boundaries because of low thermal activation energy. Meanwhile, the carbides are mainly strip-like shape with high length to width. After tempering at $630{ }^{\circ} \mathrm{C}$ (Figure 1c) and $660{ }^{\circ} \mathrm{C}$ (Figure 1d), carbides precipitated within laths increase and carbides precipitated along laths transform to short rod-like. When the temperature eventually increased to $720^{\circ} \mathrm{C}$ (Figure 1f), adjacent interfaces merge and precipitates gather at subgrains. Meanwhile, carbides have been spheroidized and coarsen obviously.

XRD tests are used to determine the type of carbide precipitates with different tempering temperatures. The results are shown in Figure 3. After being tempered at $570{ }^{\circ} \mathrm{C}$, there are mainly $\mathrm{V}$-rich $\mathrm{M}_{8} \mathrm{C}_{7}$ carbides and Fe-rich $\mathrm{M}_{3} \mathrm{C}$ type carbides. With the increase in tempering temperature, the diffraction peak intensity of $\mathrm{M}_{8} \mathrm{C}_{7}$ is getting lower and lower, which means that the relative content of $\mathrm{M}_{8} \mathrm{C}_{7}$ type carbide is decreasing. When the tempering temperature is over $690{ }^{\circ} \mathrm{C}$, the $\mathrm{M}_{8} \mathrm{C}_{7}$ type carbides almost disappear. Thus, the carbide precipitation sequence is $\mathrm{M}_{8} \mathrm{C}_{7} \rightarrow \mathrm{M}_{3} \mathrm{C}$. 


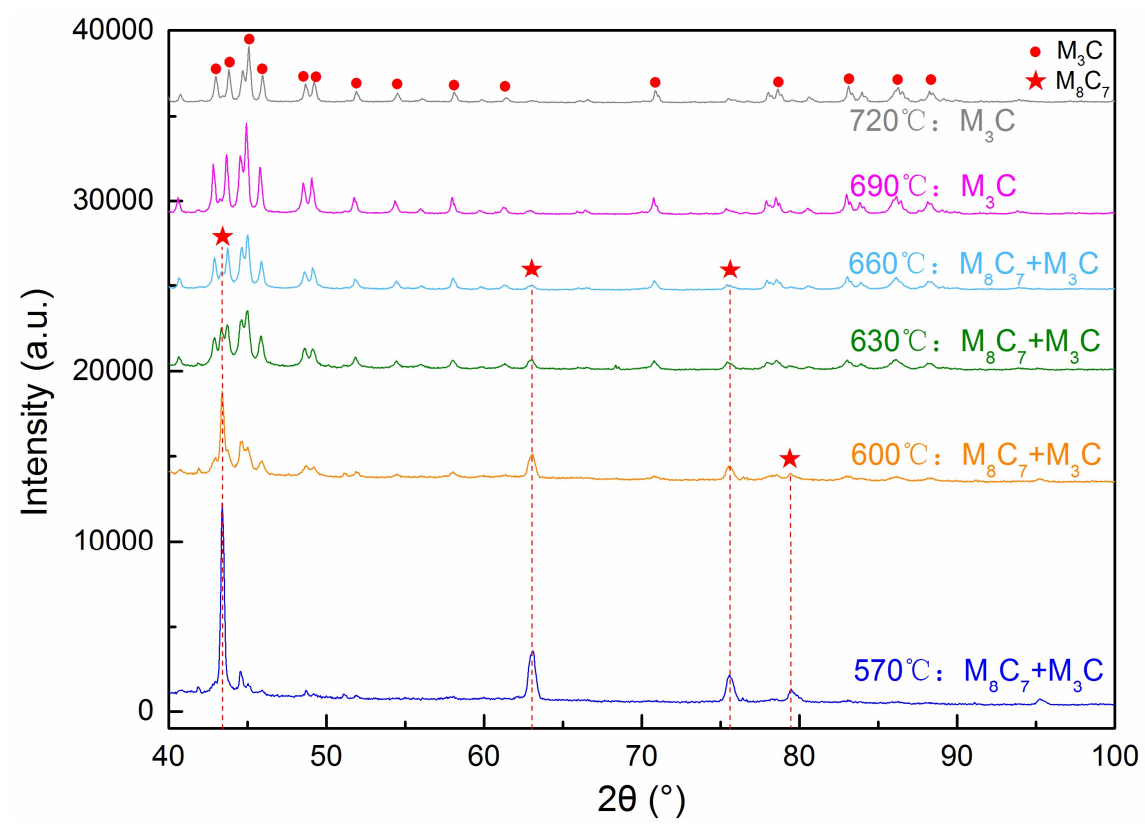

Figure 3. XRD spectra of carbides in $42 \mathrm{CrMo} 4-\mathrm{V}$ steel tempered at $570-720{ }^{\circ} \mathrm{C}$.

It is noteworthy that the presence of $\mathrm{M}_{23} \mathrm{C}_{6}$ carbides is not observed in our experiment, whereas the existence of this type of carbide in other low alloy Cr-Mo steel after tempering is reported in published literature [24,25]. The precipitation temperatures of V-rich $\mathrm{M}_{8} \mathrm{C}_{7}$ and $\mathrm{Cr}$-rich $\mathrm{M}_{23} \mathrm{C}_{6}$ are calculated to explain the difference. According to the relevant chemical equation and thermodynamic data [26-29], a precipitation reaction of $\mathrm{Cr}_{23} \mathrm{C}_{6}$ and $\mathrm{V}_{8} \mathrm{C}_{7}$ is obtained.

$$
\begin{gathered}
23[\mathrm{Cr}]+6[\mathrm{C}]=\mathrm{Cr}_{23} \mathrm{C}_{6}(\mathrm{~s}), \Delta G_{T}^{\varnothing}=-959,797.18+1172.69 T \\
8[\mathrm{~V}]+7[\mathrm{C}]=\mathrm{V}_{8} \mathrm{C}_{7}(\mathrm{~s}), \Delta G_{T}^{\varnothing}=-1,430,674.45+865.36 \mathrm{~T}
\end{gathered}
$$

The equilibrium solubility product of $\mathrm{Cr}_{23} \mathrm{C}_{6}$ and $\mathrm{V}_{8} \mathrm{C}_{7}$ obtained from Equations (1) and (2) are given by the following:

$$
\begin{gathered}
\operatorname{In}\left(w[\mathrm{Cr}]_{\%}^{23} \cdot w[\mathrm{C}]_{\%}^{6}\right)=141.05-\frac{115,443.49}{T} \\
\operatorname{In}\left(w[\mathrm{~V}]_{\%} \cdot w[\mathrm{C}]_{\%}^{0.875}\right)=13.01-\frac{21,510.02}{T}
\end{gathered}
$$

The precipitation temperatures of these carbides can be obtained by inserting the following values into Equations (3) and (4): $w[\mathrm{Cr}] \%=1.12, w[\mathrm{~V}] \%=0.19$, and $w[\mathrm{C}] \%=0.40$. The results are shown as following:

$$
\begin{gathered}
\mathrm{T}_{\mathrm{M}_{23} \mathrm{C}_{6}}=529^{\circ} \mathrm{C} \\
\mathrm{T}_{\mathrm{M}_{8} \mathrm{C}_{7}}=1117^{\circ} \mathrm{C}
\end{gathered}
$$

When the temperature is below the precipitation temperature, the carbides will precipitate. In this study, all the test temperatures are higher than $529^{\circ} \mathrm{C}$, so $M_{23} C_{6}$ cannot be precipitated.

Further observations on the morphologies and compositions of carbides of $42 \mathrm{CrMo} 4-\mathrm{V}$ steel tempered at various temperatures are shown in Figure 4. Combined with XRD results and EDX results, it can be found that after being tempered at $570{ }^{\circ} \mathrm{C}$ (Figure 4a) the long strip-like carbides are $\mathrm{M}_{3} \mathrm{C}$ and most of them are between $300 \mathrm{~nm}$ and $600 \mathrm{~nm}$. After being tempered at $630^{\circ} \mathrm{C}$ (Figure $4 \mathrm{~b}$ ), the short rod-like carbides are $M_{3} C$ and the spherical carbides are $M_{8} C_{7}$. The length of $M_{3} C$ are 150-300 nm and the diameter of $\mathrm{M}_{8} \mathrm{C}_{7}$ are less than $100 \mathrm{~nm}$. When the temperature increased to $720{ }^{\circ} \mathrm{C}$ (Figure $4 \mathrm{c}$ ), the irregular spherical carbides are $\mathrm{M}_{3} \mathrm{C}$ with a diameter of $150-200 \mathrm{~nm}$. 
From the above results, it can be found that with increasing tempering temperature, the spheroidizing process of $\mathrm{M}_{3} \mathrm{C}$ carbides can be divided into two stages. First, the lengths of $\mathrm{M}_{3} \mathrm{C}$ carbides diminish from 300-600 nm to 150-200 nm while the widths are basically unchanged. Second, the widths of $\mathrm{M}_{3} \mathrm{C}$ carbides coarsen but the lengths remain unchanged. The changes in the length and width of $\mathrm{M}_{3} \mathrm{C}$ carbides are carried out separately rather than simultaneously.
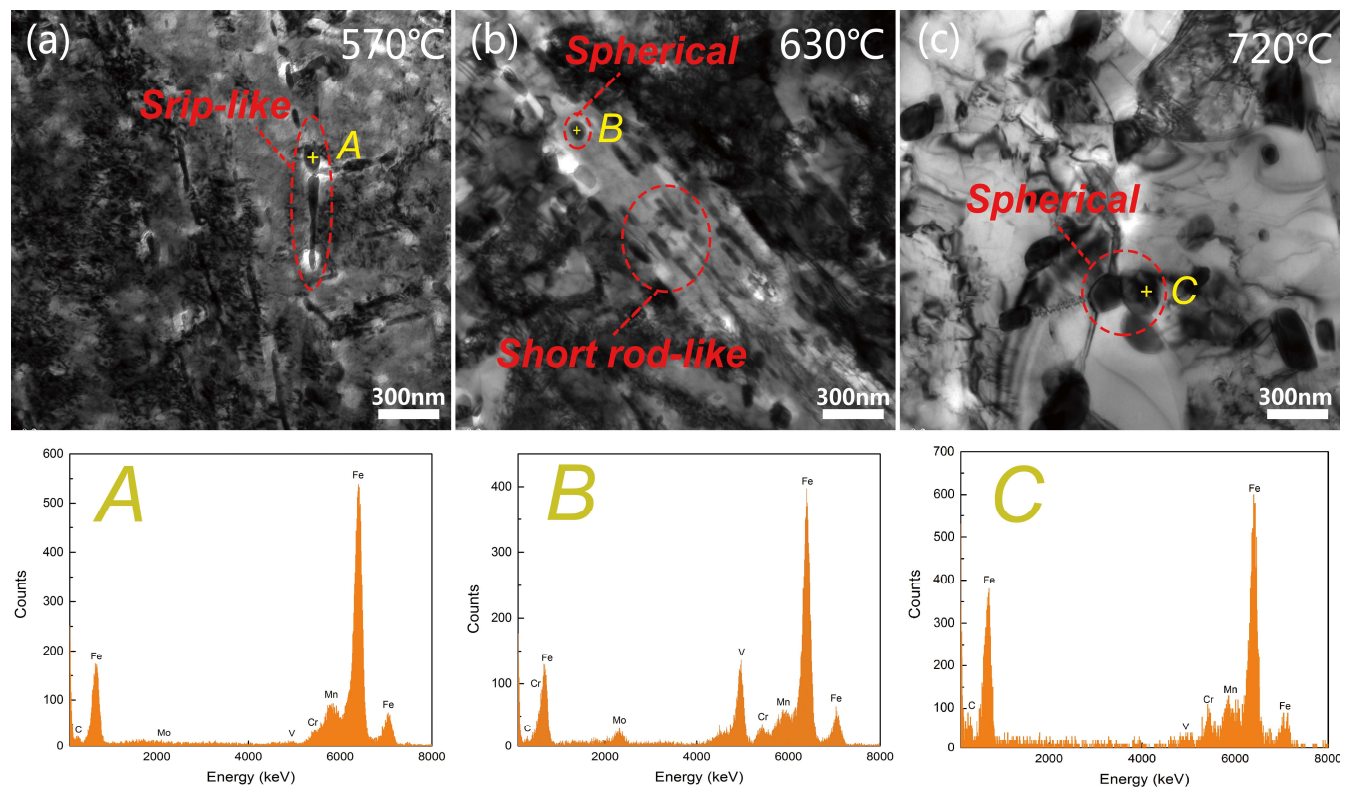

Figure 4. TEM and EDX results showing the evolution of carbides in 42CrMo4-V steel tempered at (a) $570{ }^{\circ} \mathrm{C}$; (b) $630{ }^{\circ} \mathrm{C}$; (c) $720^{\circ} \mathrm{C}$.

Furthermore, according to experimental results and theoretical calculations combined with published literature, it can be concluded that $\mathrm{M}_{8} \mathrm{C}_{7}$ carbides precipitate at a higher temperature (about $1390 \mathrm{~K}$ ), but it has a slow coarsening speed (Figure $4 \mathrm{~b}$ ). While $\mathrm{M}_{3} \mathrm{C}$ carbides precipitate at a lower temperature (about $1023 \mathrm{~K}$ ) [30], but it has a fast coarsening speed (Figure 4b). The reason is mainly that $\mathrm{Fe}$ and $\mathrm{Cr}$ have greater diffusion rate than that of $\mathrm{V}$ [29]. The driving force of the precipitation of $\mathrm{M}_{8} \mathrm{C}_{7}$ carbides is larger because of its higher precipitation temperature, so the requirement of the nucleation sites of $\mathrm{M}_{8} \mathrm{C}_{7}$ carbides is lower and $\mathrm{M}_{8} \mathrm{C}_{7}$ carbides are more widely dispersed.

\subsection{Impact Energy}

Figure 5 shows the absorbed energy of $42 \mathrm{CrMo} 4-\mathrm{V}$ steel tempered at different temperatures. The absorbed energies of $42 \mathrm{CrMo} 4-\mathrm{V}$ steel were found to increase significantly from $21.7 \mathrm{~J}$ to $132.3 \mathrm{~J}$ with increasing tempering temperatures from $570{ }^{\circ} \mathrm{C}$ to $720^{\circ} \mathrm{C}$. The fracture surfaces of impact specimens are shown in Figure 6. Only the samples with representative result are displayed. The macro fractographs are shown in Figure $6 \mathrm{a}-\mathrm{f}$. After the $570{ }^{\circ} \mathrm{C}$ temper (Figure 6a), the radial region, which is known as the crack unstable propagation region as well as the crack rapid propagation region, takes up most of the fracture surface and the shear lip is thin, indicating that the failure mode is a brittle fracture. The thickness of shear lip increases and the area of radial region reduces with increasing tempering temperatures from $600{ }^{\circ} \mathrm{C}$ (Figure 6b) to $720^{\circ} \mathrm{C}$ (Figure 6f), indicating that the mode of fracture evolves from brittle to ductile as the tempering temperature rise [31]. Figure $6 \mathrm{~g}-\mathrm{i}$ is high-magnification images of zone 1, 3 and 5 in Figure 6a-f, respectively. With increasing tempering temperature, the dimple fractures in radial region increase, indicating that the failure mode of radial region transforms from cleavage fractures to quasi-cleavage fractures, a failure mode between brittle fracture and ductile fracture. Figure 6j-1 is high-magnification images of zone 2, 4 and 6 in Figure 6a-f, respectively. It can be found that dimples in fibrous zones become larger and deeper with increasing tempering 
temperature. A large number of microscopic voids form and grow inside the metal under the external force. The sample fractures when the voids connect to each other. The void remained in the fracture surfaces is the dimple. The large size of dimple means that the material has a large plastic deformation before the fracture, so samples with large dimples have a preferable impact toughness [23,32]. With increasing tempering temperature from $570{ }^{\circ} \mathrm{C}$ to $720^{\circ} \mathrm{C}$, the proportion of dimple fractures increase and the dimples become larger and deeper, resulting in the increase of absorbed energy [23].

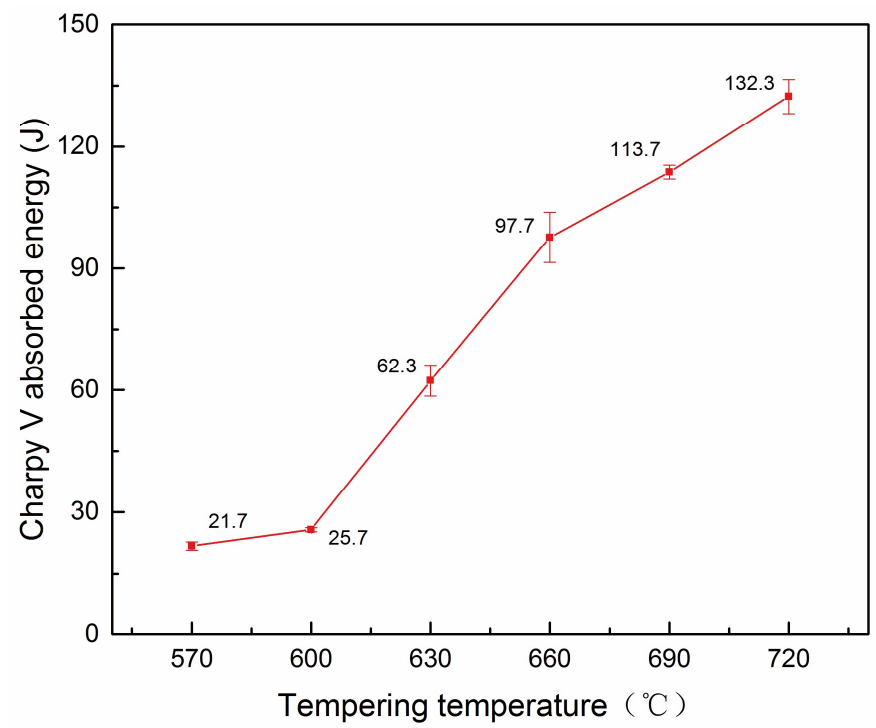

Figure 5. Absorbed energy at $-30^{\circ} \mathrm{C}$ of $42 \mathrm{CrMo} 4-\mathrm{V}$ steel tempered at different temperature.
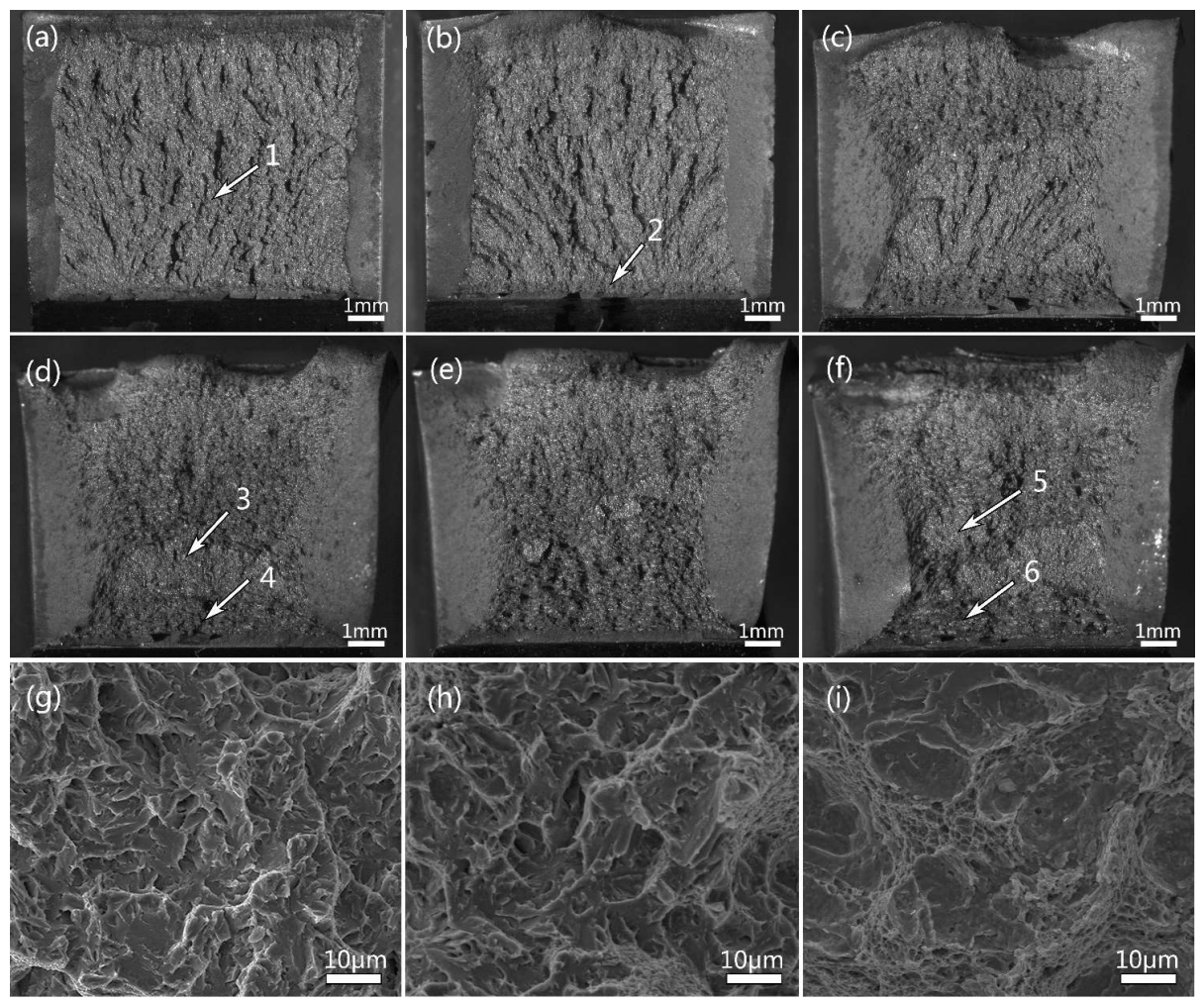

Figure 6. Cont. 

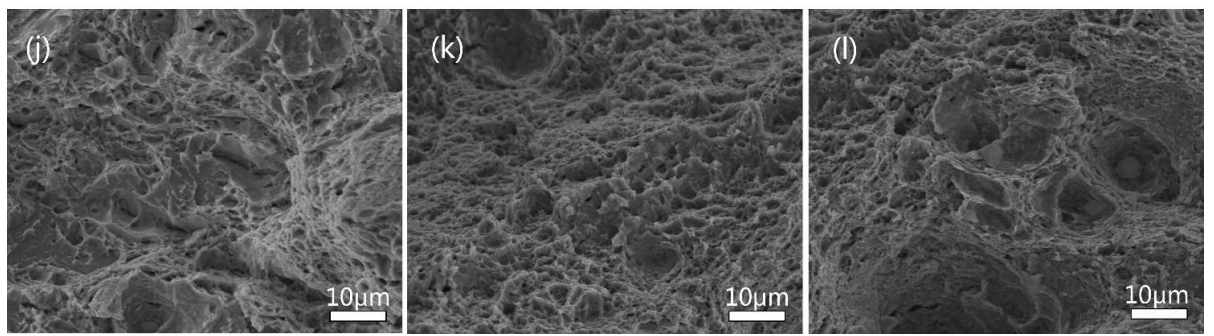

Figure 6. Macro fractographs of $42 \mathrm{CrMo} 4-\mathrm{V}$ steel tempered at (a) $570{ }^{\circ} \mathrm{C}$; (b) $600{ }^{\circ} \mathrm{C}$; (c) $630{ }^{\circ} \mathrm{C}$; (d) $660{ }^{\circ} \mathrm{C}$; (e) $690{ }^{\circ} \mathrm{C}$; (f) $720{ }^{\circ} \mathrm{C}$; (g-i) are high-magnification images of zone 1, 3 and 5 in (a-f), respectively, $(\mathbf{j}-\mathbf{k})$ are high-magnification images of zone 2,4 and 6 in $(\mathbf{a}-\mathbf{f})$, respectively.

\subsection{Mechanisms}

It can be seen that the low temperature toughness increases significantly with the increase of tempering temperature. A major factor for the increase is the softening of matrix. During the fracture process, the propagation of a crack depends on the stress concentration at the crack tip. When the stress concentration is high enough to exceed the yield strength of the metal, plastic deformation occurs and there is a plastic deformation region around the crack tip. Furthermore, the softer the base metal, the larger the plastic deformation region. Additionally, large plastic deformation district will result in slower crack propagation and larger absorbed energy [23].

There are mainly two reasons for the softening of the base metal: the decrease of dislocation strengthening and solid solution strengthening. The decrease of dislocation strengthening is due to the decrease of dislocation density. The dislocation density of $42 \mathrm{CrMo} 4-\mathrm{V}$ steel tempered at different temperatures was calculated from XRD spectra (Figure 7) and the results are shown in Figure 8. With increasing tempering temperature from $570{ }^{\circ} \mathrm{C}$ to $720{ }^{\circ} \mathrm{C}$, the dislocation density decreased from $4.08 \times 10^{14} \cdot \mathrm{m}^{-2}$ to $0.94 \times 10^{14} \cdot \mathrm{m}^{-2}$. With increasing tempering temperature, the dislocations move, then merge and eventually annihilate, leading to the reduction of dislocation density. Moreover, dislocation movement can relieve the local stress concentration. As a result, crack initiation delays. Once the crack is initiated, dislocation movement can reduce the stress peak at the crack tip and hinder the crack propagation [22].

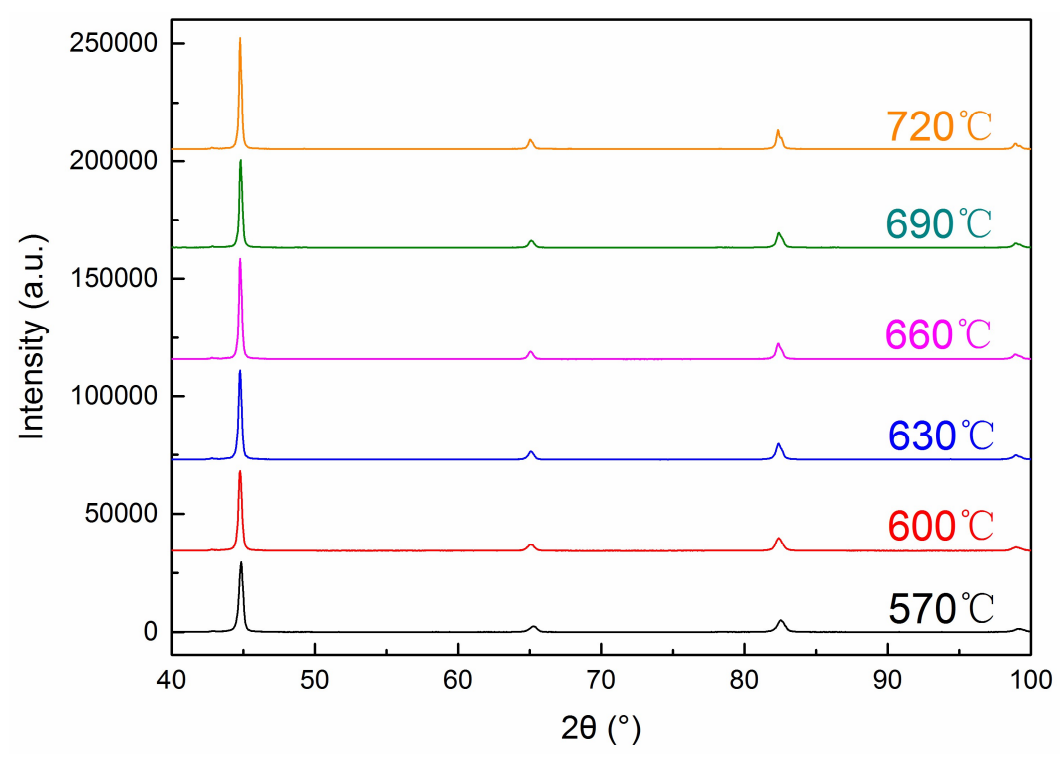

Figure 7. XRD spectra of $42 \mathrm{CrMo} 4-\mathrm{V}$ steel tempered at $570-720{ }^{\circ} \mathrm{C}$. 


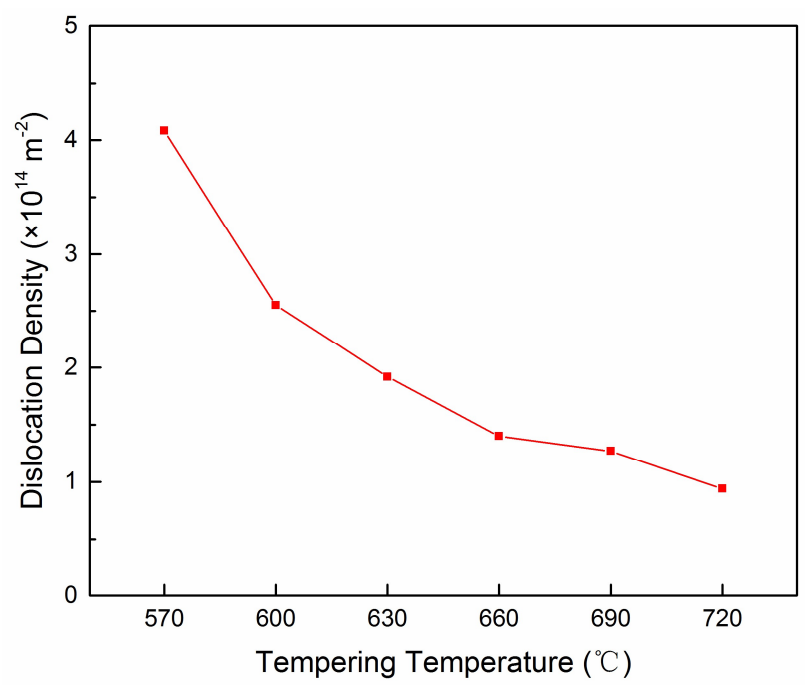

Figure 8. Dislocation density of $42 \mathrm{CrMo} 4-\mathrm{V}$ steel tempered at $570-720^{\circ} \mathrm{C}$.

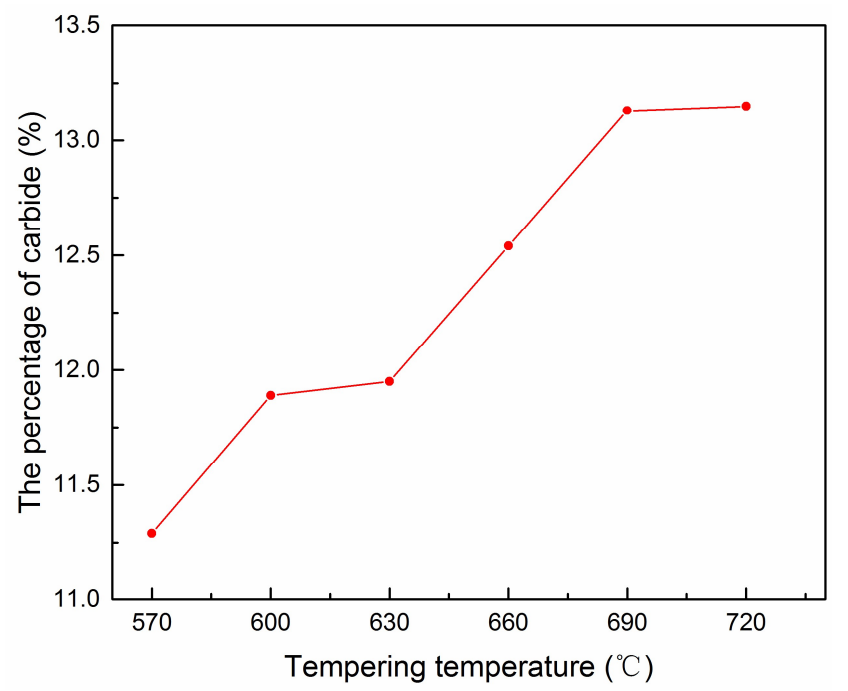

Figure 9. Percentage of carbides in $42 \mathrm{CrMo} 4-\mathrm{V}$ steel tempered at $570-720{ }^{\circ} \mathrm{C}$.

The decrease of solid solution strengthening is mainly due to the precipitation of carbide, which leads to the decrease of the degree of supersaturation of the matrix [33]. Figure 9 shows the relationship between the percentage of carbides and the tempering temperature. It demonstrates that the percentage of carbides increases with the increase in tempering temperature. The more precipitates mean the more interstitial atoms, especially $\mathrm{C}$ atoms, dissolve in the matrix precipitated from the supersaturation solid solution, resulting in the decrease of the degree of supersaturation. In $42 \mathrm{CrMo} 4-\mathrm{V}$ steel, with increasing tempering temperature from $570{ }^{\circ} \mathrm{C}$ to $720^{\circ} \mathrm{C}$, the matrix metal becomes softer, the plastic deformation region around the crack tip becomes larger, resulting in a preferable low temperature impact toughness.

Another factor for the increase in low temperature impact toughness is the evolution of carbides. The evolution includes three aspects: morphology, distribution and size. The morphologies of carbides change from lamella to short rod and finally to globosity as the tempering temperature increases from $570{ }^{\circ} \mathrm{C}$ to $720{ }^{\circ} \mathrm{C}$. Meanwhile, the distribution of carbides changes gradually from the continuous distribution along the martensite lath to the dispersive distribution. The lamellar carbide is a brittle phase, and it is easy to produce lager stress concentration which in turn leads to microcracks [34]. Further, microcracks can expand rapidly along the continuously distributed lamellar carbides [35]. 
As a result, a poor low temperature impact toughness of $42 \mathrm{CrMo} 4-\mathrm{V}$ steel is obtained after tempering at $570{ }^{\circ} \mathrm{C}$, only about $21.7 \mathrm{~J}$. With the increase of tempering temperature, the stress concentration decreases significantly when the carbides become short stick, leading to the significant increase of crack forming energy. Moreover, as the carbide was no longer continuous, the crack propagation becomes difficult, so the crack propagation energy also increases. After being tempered at $720{ }^{\circ} \mathrm{C}$, carbide precipitates dispersed in the globosity, so there is a further increase in the crack forming energy and propagation energy and the absorbed energy increase to about $132.3 \mathrm{~J}$.

The grain structure also has an important effect in the low temperature impact toughness of $42 \mathrm{CrMo} 4-\mathrm{V}$ steel. From Figure 10, the percentage of grain misorientation angle higher than $15^{\circ}$ is $46.91 \%$ when tempering at $720{ }^{\circ} \mathrm{C}$, while, it is only $41.28 \%$ at $570{ }^{\circ} \mathrm{C}$, indicating that some lath boundaries change gradually from the small angle boundary to the large angle boundary with increasing tempering temperature. The reason for this trend is the dislocation movement and the recovery of martensite lath. During the fracture process, the crack propagation direction will be changed when it suffers the large angle boundaries, resulting in the winding crack propagation paths and the larger crack propagation energy [36,37]. As a result, high temperature tempering with larger amount of large angle boundaries leads to a preferable toughness.
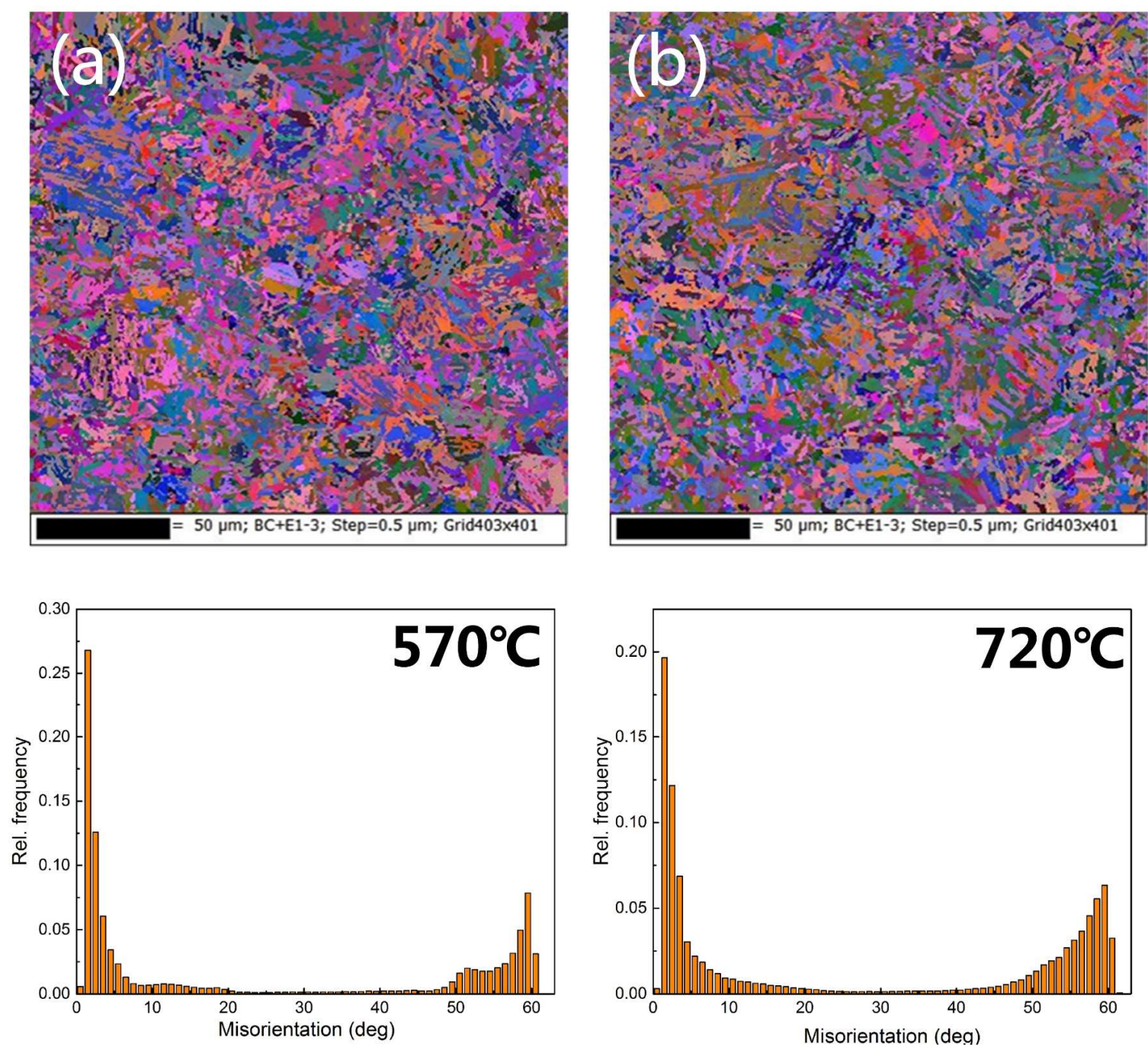

Figure 10. EBSD images and misorientations when tempered at: (a) $570{ }^{\circ} \mathrm{C}$; (b) $720^{\circ} \mathrm{C}$. 


\section{Conclusions}

The effect of tempering temperature on the low temperature impact toughness of $42 \mathrm{CrMo} 4-\mathrm{V}$ steel is studied on the basis of microstructures after tempering at $570-720^{\circ} \mathrm{C}$ for $3 \mathrm{~h}$. The results are summarized as follows:

1. The addition of $\mathrm{V}$ to $42 \mathrm{CrMo} 4$ steel leads to the appearance of $\mathrm{M}_{8} \mathrm{C}_{7}$ type carbides, and the carbide precipitation sequence of $42 \mathrm{CrMo} 4-\mathrm{V}$ steel is $\mathrm{M}_{8} \mathrm{C}_{7} \rightarrow \mathrm{M}_{3} \mathrm{C}$. As the tempering temperature increases, the spheroidizing process of $\mathrm{M}_{3} \mathrm{C}$ carbides can be divided into two stages and it has a significant effect on the low temperature impact toughness.

2. With the increase of tempering temperature from $570{ }^{\circ} \mathrm{C}$ to $720^{\circ} \mathrm{C}$, the low temperature impact energy of $42 \mathrm{CrMo} 4-\mathrm{V}$ steel increases greatly from $26 \mathrm{~J}$ to $132 \mathrm{~J}$. The changes of toughness are attributed to the evolution of microstructure, including the softening of matrix metal, the evolution of carbide precipitates and grain structures.

Acknowledgments: This work was financially supported by the National Key Research and Development Program of China (2016YFB0300401).

Author Contributions: Chen Sun carried out the experiments and analysis of the results. Pai-Xian Fu, Hang-Hang Liu and Ning-Yu Du prepared and revised the manuscript. Hong-Wei Liu contributed in the interpretation and discussion of results.

Conflicts of Interest: The authors declare no conflict of interest.

\section{References}

1. Quan, G.Z.; Li, G.S.; Chen, T.; Wang, Y.X.; Zhang, Y.W.; Zhou, J. Dynamic recrystallization kinetics of 42CrMo steel during compression at different temperatures and strain rates. Mater. Sci. Eng. A 2011, 528, 4643-4651. [CrossRef]

2. Demir, T.; Übeyli, M.; Yıldırım, R.O. Investigation on the ballistic impact behavior of various alloys against $7.62 \mathrm{~mm}$ armor piercing projectile. Mater. Des. 2008, 29, 2009-2016. [CrossRef]

3. Jiang, B.; Zhou, L.; Wen, X.; Zhang, C.L.; Liu, Y.Z. Heat Treatment Properties of 42CrMo Steel for Bearing Ring of Varisized Shield Tunneling Machine. Acta Metall. Sin. 2014, 27, 383-388. [CrossRef]

4. Ilhan, E.; Findik, F.; Aslanlar, S. An investigation of the factors affecting the design of drum dryers. Mater. Des. 2003, 24, 503-507. [CrossRef]

5. Chaouch, D.; Guessasma, S.; Sadok, A. Finite Element simulation coupled to optimisation stochastic process to assess the effect of heat treatment on the mechanical properties of 42CrMo4 steel. Mater. Des. 2012, 34, 679-684. [CrossRef]

6. Nouari, M.; Molinari, A. Experimental verification of a diffusion tool wear model using a $42 \mathrm{CrMo} 4$ steel with an uncoated cemented tungsten carbide at various cutting speeds. Wear 2005, 259, 1151-1159. [CrossRef]

7. Starke, P.; Walther, F.; Eifler, D. New fatigue life calculation method for quenched and tempered steel SAE 4140. Mater. Sci. Eng. A 2009, 523, 246-252. [CrossRef]

8. Klocke, F.; Schneider, S.; Ehle, L.; Meyer, H.; Hensgen, L.; Klink, A. Investigations on Surface Integrity of Heat Treated 42CrMo4 (AISI 4140) Processed by Sinking EDM. Procedia CIRP 2016, 42, 580-585. [CrossRef]

9. Kreethi, R.; Mondal, A.K.; Dutta, K. Ratcheting fatigue behaviour of 42CrMo4 steel under different heat treatment conditions. Mater. Sci. Eng. A 2017, 679, 66-74. [CrossRef]

10. Nikitin, I.; Besel, M. Correlation between residual stress and plastic strain amplitude during low cycle fatigue of mechanically surface treated austenitic stainless steel AISI 304 and ferritic-pearlitic steel SAE 1045. Mater. Sci. Eng. A 2008, 491, 297-303. [CrossRef]

11. Nagarajan, V.; Putatunda, S.; Boileau, J. Fatigue Crack Growth Behavior of Austempered AISI 4140 Steel with Dissolved Hydrogen. Metals 2017, 7, 466. [CrossRef]

12. Ulutan, M.; Celik, O.N.; Gasan, H.; Er, U. Effect of Different Surface Treatment Methods on the Friction and Wear Behavior of AISI 4140 Steel. J. Mater. Sci. Technol. 2010, 26, 251-257. [CrossRef]

13. Miokovic, T.; Schulze, V.; Vohringer, O.; Löhe, D. Influence of cyclic temperature changes on the microstructure of AISI 4140 after laser surface hardening. Acta Mater. 2007, 55, 589-599. [CrossRef] 
14. Zhang, Z.; Yin, Z.; Han, T.; Tan, A.C.C. Fracture analysis of wind turbine main shaft. Eng. Fail. Anal. 2013, 34, 129-139. [CrossRef]

15. Wang, X.; Zeng, X.; Li, J.; Yang, X.; Wang, H.J. A review on recent advancements of substructures for offshore wind turbines. Energy Convers. Manag. 2018, 158, 103-119. [CrossRef]

16. Staśko, R.; Adrian, H.; Adrian, A. Effect of nitrogen and vanadium on austenite grain growth kinetics of a low alloy steel. Mater. Charact. 2006, 56, 340-347. [CrossRef]

17. Scott, C.P.; Fazeli, F.; Amirkhiz, B.S.; Pushkareva, I.; Allain, S.Y.P. Structure-properties relationship of ultra-fine grained V-microalloyed dual phase steels. Mater. Sci. Eng. A 2017, 703, 293-303. [CrossRef]

18. Di Schino, A.; Guarnachelli, C. Microstructure and cleavage resistance of high strength steels. Mater. Sci. Forum 2010, 638-642, 3188-3193. [CrossRef]

19. Ceschini, L.; Marconi, A.; Martini, C.; Morri, A.; Di Schino, A. Tensile and impact behaviour of a microalloyed medium carbon steel: Effect of the cooling condition and corresponding microstructure. Mater. Des. 2013, 45, 171-178. [CrossRef]

20. Chen, J.D.; Mo, W.L.; Wang, P.; Lu, S.P. Effects of tempering temperature on the impact toughness of steel 42CrMo. Acta Metall. Sin. 2012, 48, 1186-1193. [CrossRef]

21. Furukawa, S.; Ihara, H.; Murata, Y.; Tsukada, Y.; Koyama, T. Simulation of dislocation recovery in lath martensite steels using the phase-field method. Comput. Mater. Sci. 2016, 119, 108-113. [CrossRef]

22. Liu, H.H.; Fu, P.X.; Liu, H.W.; Sun, C.; Ma, X.P.; Li, D.Z. Microstructure evolution and mechanical properties in 718H pre-hardened mold steel during tempering. Mater. Sci. Eng. A 2018, 709, 181-192. [CrossRef]

23. Yan, P.; Liu, Z.; Bao, H.; Weng, Y.Q.; Liu, W. Effect of tempering temperature on the toughness of 9Cr-3W-3Co martensitic heat resistant steel. Mater. Des. 2014, 54, 874-879. [CrossRef]

24. Dong, J.; Zhou, X.; Liu, Y.; Li, C.; Liu, C.X.; Guo, Q.Y. Carbide precipitation in Nb-V-Ti microalloyed ultra-high strength steel during tempering. Mater. Sci. Eng. A 2017, 683, 215-226. [CrossRef]

25. Janovec, J.; Svoboda, M.; Výrostková, A.; Kroupa, A. Time-temperature-precipitation diagrams of carbide evolution in low alloy steels. Mater. Sci. Eng. A 2005, 402, 288-293. [CrossRef]

26. Ning, A.; Mao, W.; Chen, X.; Guo, H.J.; Guo, J. Precipitation Behavior of Carbides in H13 Hot Work Die Steel and Its Strengthening during Tempering. Metals 2017, 7, 70. [CrossRef]

27. Ye, D.L.; Hu, J.H. Practical Inorganic Thermodynamic Data Manual, 2nd ed.; Metallurgical Industry Press: Beijing, China, 2002.

28. Chen, J.X. Steelmaking Common Chart Data Manual, 2nd ed.; Metallurgical Industry Press: Beijing, China, 2010.

29. Yong, Q.L. The Second Phase of the Steel Materials; Metallurgical Industry Press: Beijing, China, 2006.

30. Chen, J.D. Microstructure and Defect Research of 42CrMo Steel Forgings for Nuclear Polar Crane. Master's Thesis, University of Chinese Academy of Sciences, Beijing, China, May 2013. (In Chinese)

31. Chao, Y.J.; Ward, J.D., Jr.; Sands, R.G. Charpy impact energy, fracture toughness and ductile-brittle transition temperature of dual-phase 590 steel. Mater. Des. 2007, 28, 551-557. [CrossRef]

32. Zhong, Q.P.; Zhao, Z.H. Fractography; Higher Education Press: Beijing, China, 2006.

33. Hao, L.H.; Xiao, N.M.; Zheng, C.W.; Li, D.Z. Mechanical Properties and Temper Resistance of Deformation Induced Ferrite in a Low Carbon Steel. J. Mater. Sci. Technol. 2010, 26, 1107-1113. [CrossRef]

34. Li, J.; Zhang, C.; Jiang, B.; Zhou, L.Y.; Liu, Y.Z. Effect of large-size $\mathrm{M}_{23} \mathrm{C}_{6}$-type carbides on the low-temperature toughness of martensitic heat-resistant steels. J. Alloys Compd. 2016, 685, 248-257. [CrossRef]

35. Cui, Y.X.; Wang, C.L. Metal Fracture Analysis; Harbin Industrial University Press: Harbin, China, 1998.

36. Liu, J.; Yu, H.; Zhou, T.; Song, C.H.; Zhang, K. Effect of double quenching and tempering heat treatment on the microstructure and mechanical properties of a novel $5 \mathrm{Cr}$ steel processed by electro-slag casting. Mater. Sci. Eng. A 2014, 619, 212-220. [CrossRef]

37. Wang, C.; Wang, M.; Shi, J.; Hui, W.J.; Dong, H. Effect of microstructural refinement on the toughness of low carbon martensitic steel. Scr. Mater. 2008, 58, 492-495. [CrossRef]

(C) 2018 by the authors. Licensee MDPI, Basel, Switzerland. This article is an open access article distributed under the terms and conditions of the Creative Commons Attribution (CC BY) license (http:/ / creativecommons.org/licenses/by/4.0/). 